\author{
Bogdan Kosowskia), Artur Luzar ${ }^{\mathrm{b})}$ \\ a) The Jagiellonian University, Institute of Political Science and International Relations / Uniwersytet Jagielloński, Instytut Nauk \\ Politycznych i Stosunków Międzynarodowych \\ b) Fire Service College of the State Fire Service in Kraków, National Safety Department / Szkoła Aspirantów Państwowej Straży \\ Pożarnej w Krakowie, Zakład Bezpieczeństwa Narodowego \\ Corresponding author / Autor korespondencyjny: bogdan.kosowski@gmail.com
}

\title{
Social Media as a Source of Information and Misinformation on the Example of the Notre Dame Fire
}

\section{Wybrane media społecznościowe w komunikacji kryzysowej na przykładzie pożaru katedry Notre Dame}

\begin{abstract}
Purpose: The aim of this article is to analyse the activity of individual users, institutions and organisations in social media in the context of the fire in the Notre Dame Cathedral. The main threats of using this type of tools in crisis communication are presented, with particular emphasis on the propagation of information and disinformation.

Introduction: The development of social media (platforms) in the global Internet means that they have become a tool commonly used by various types of private organisations, public administration and services. Using this medium gives great opportunities in the process of providing current information, efficient communication with the local community, building positive relations and creating a positive image of the organisation. Social media are also used by the government administration and emergency services of many countries during each of the four phases of crisis management (mitigation, preparedness, response, recovery). Information and communication technologies together with social media play an important role in contemporary people's lives. They constitute an important part of everyday reality and are intrinsically related to it. The fire of the Notre Dame Cathedral in 2019 was widely commented on social media. The existing traditional methods of communication, such as press, television or radio, have significant limitations consisting in the inability to interact with the media users. Only the person who created the information could be the broadcaster. The internet, and social media in particular, has changed dramatically this state of affairs, giving recipients the opportunity to interact with people/institutions generating content. Methodology: The method applied in the article is that of literature review in the area of Web 1.0, Web 2.0, Web 3.0 development as well as the course of the fire of the Notre Dame Cathedral. Statistical analysis was performed using Google Trends. The paper indicates the main sources of opportunities and threats to users' activity in social media, with particular emphasis on the aspects related to the efficient operation of emergency services.

Conclusions: The role of social media in crisis situations has not yet been established. It is evolving and it can be expected that with time it will be used to an increasing extent also in cases such as fires and other threats to cultural goods. The authors recommend further research on the behaviour of users of social networking sites, groups and the entire portal.

Keywords: social media, misinformation, fake news, Notre Dame fire, citizen journalism

Type of article: case study
\end{abstract}

Received: 15.09.2020; Reviewed: 28.09.2020; Accepted: 20.10.2020;

Authors` ORCID IDs: B. Kosowski - 0000-0003-3397-4445; A. Luzar - 0000-0003-2263-1164;

The authors contributed the equally to this article;

Please cite as: SFT Vol. 56 Issue 2, 2020, pp. 6-20, https://doi.org/10.12845/sft.56.2.2020.1;

This is an open access article under the CC BY-SA 4.0 license (https://creativecommons.org/licenses/by-sa/4.0/).

\section{ABSTRAKT}

Cel: Celem artykułu jest analiza aktywności użytkowników indywidualnych, instytucji i organizacji w mediach społecznościowych w kontekście pożaru katedry Notre Dame. Przedstawiono główne zagrożenia związane z wykorzystaniem tego typu narzędzi w komunikacji kryzysowej ze szczególnym uwzględnieniem propagowania informacji i dezinformacji.

Wprowadzenie: Rozwój mediów (platform) społecznościowych w ogólnoświatowej sieci Internet sprawił, że są one uznawane za narzędzie powszechnie wykorzystywane przez różnego typu organizacje prywatne, administrację publiczną oraz służby. Używanie tego medium daje duże możliwości w procesie przekazywania bieżących informacji, sprawnego komunikowania się ze społecznością lokalną, budowania pozytywnych relacji i kreowania wizerunku organizacji. Media społecznościowe (social media) są także wykorzystywane przez administrację rządową oraz służby ratownicze wielu krajów w czasie 
każdej z czterech faz zarządzania kryzysowego (zapobieganie, przygotowanie, reagowanie, odbudowa). Technologie informacyjno-komunikacyjne oraz media społecznościowe odgrywają istotną rolę w rzeczywistości otaczającej współczesnego człowieka, towarzyszą mu w wielu dziedzinach życia i są wręcz jego nieodłączną częścią. Pożar katedry Notre Dame w 2019 roku był szeroko komentowany w mediach społecznościowych. Dotychczasowe tradycyjne metody komunikacji, takie jak prasa, telewizja czy też radio, mają istotne ograniczenia polegające na braku możliwości interakcji z odbiorcą. Wyłącznie osoba tworząca komunikat mogła być nadawcą. Internet, a w szczególności media społecznościowe, diametralnie zmienił ten stan rzeczy, dając odbiorcom możliwość interakcji z osobami/instytucjami generującymi treść.

Metodologia: W niniejszym artykule wykorzystano metodę analizy literaturowej w zakresie rozwoju sieci Web 1.0 - Web 3.0 oraz przebiegu pożaru katedry Notre Dame. Analizy statystycznej dokonano za pomocą Google Trends. W pracy wskazane zostały aktywności użytkowników w mediach społecznościowych ze szczególnym uwzględnieniem aspektów związanych ze skuteczną działalnością służb ratowniczych.

Wnioski: Rola mediów społecznościowych w sytuacjach kryzysowych nie jest zamknięta, a wręcz przeciwnie - jest rozwojowa i można spodziewać się, że z biegiem czasu będzie wykorzystywana w coraz szerszym zakresie, także w przypadkach, takich jak pożary i inne zagrożenia dla dóbr kultury. Autorzy postulują prowadzenie dalszych badań w zakresie zachowania się użytkowników, grup oraz całego portalu.

Słowa kluczowe: media społecznościowe, dezinformacja, Notre Dame, dziennikarstwo obywatelskie

Typ artykułu: studium przypadku

Przyjęty: 15.09.2020; Zrecenzowany: 28.09.2020; Zaakceptowany: 20.10.2020;

Identyfikatory ORCID autorów: B. Kosowski - 0000-0003-3397-4445; A. Luzar - 0000-0003-2263-1164;

Autorzy wnieśli równy wkład merytoryczny w powstanie artykułu;

Proszę cytować: SFT Vol. 56 Issue 2, 2020, pp. 6-20, https://doi.org/10.12845/sft.56.2.2020.1;

Artykuł udostępniany na licencji CC BY-SA 4.0 (https://creativecommons.org/licenses/by-sa/4.0/).

\section{Introduction}

Transparent, planned and practiced communication with an internal and external environment is the foundation of the good and effective operation of every organisation, in particular, public administration institutions. The main goal of a communication process is the exchange of information among the parties involved, and it aims to develop a common interpretation of a given situation. Communication should also be considered in the context of the mutual attitude of the parties involved towards interaction and information flow in a one-way or multi-directional way. It should be noted that in the case of a one-way communication, the sender is oriented towards the distribution of his assessment of the situation to other recipients, which takes into account the discrepancy in attitude, knowledge or propensity to act and may turn out to be ineffective.

Communication can also be perceived in terms of interaction which also includes information obtained from social partners. Modern ways of communication are largely based on communication space in the global network - the Internet.

Since the beginning of the 1990s, there has been a rapid development of communication technologies and socio-organizational and legal conditions, of which the signing of the Maastricht Treaty on February 7, 1992, played an important role. The document indicated the necessity of pluralism in the media as a response to the needs of every democratic society [1]. The Internet has become a place where the possibility of social change was noticed. The popular global network turned into a space for the exchange of experiences and information, where individual users could freely give each other advice and help, but also publish potentially discrediting, false or offensive information. The broad spectrum of applications of communication techniques on the Internet has resulted in the interest in their use by business, government administration entities and political parties [2].

\section{Wstęp}

Przejrzysta, zaplanowana i przećwiczona komunikacja z otoczeniem wewnętrznym i zewnętrznym jest fundamentem dobrego i efektywnego funkcjonowania każdej organizacji, a w szczególności instytucji administracji publicznej. Zasadniczym celem procesu komunikowania się jest wymiana informacji wśród zaangażowanych podmiotów. Pojęcie to należy rozpatrywać także w kontekście wzajemnego nastawienia podmiotów na interakcję oraz przepływu informacji w sposób jedno- lub wielokierunkowy. Należy zaznaczyć, że w przypadku komunikacji jednostronnej nadawca jest zorientowany na przekazanie swojej oceny sytuacji pozostałym odbiorcom, co - biorąc pod uwagę rozbieżność w nastawieniu, wiedzy lub skłonności do działania - może okazać się mało efektywne.

Komunikacja może być także postrzegana w charakterze interakcji poprzez wzajemne porozumiewanie się z uwzględnieniem informacji pozyskanych także od partnerów społecznych. Współczesne sposoby komunikowania się wykorzystują w dużej mierze przestrzenie komunikacyjne w globalnej sieci Internet.

Z początkiem lat 90. XX w. nastąpił gwałtowny rozwój technologii komunikacyjnych oraz uwarunkowań społeczno-organizacyjno-prawnych, spośród których istotną rolę odegrało podpisanie traktatu z Maastricht 7 lutego 1992 r. W dokumencie tym wskazano na konieczność pluralizmu w mediach jako odpowiedź na potrzeby każdego społeczeństwa demokratycznego [1]. Internet stał się miejscem, w którym zaczęto dostrzegać możliwość przemian społecznych. Coraz bardziej popularna globalna sieć przekształciła się w przestrzeń do wymiany doświadczeń i informacji, gdzie poszczególni użytkownicy w swobodny sposób mogli udzielać sobie nawzajem wskazówek, pomocy, ale także publikować informacje dyskredytujące innych, nieprawdziwe lub też obraźliwe. Szerokie spektrum zastosowań technik komunikacyjnych w Internecie spowodowało zainteresowanie ich 
Since the signing of the Maastricht treaty, the communication space on the Internet has constantly been evolving through the development of three individual stages of the global network (conventionally called Web 1.0, 2.0, 3.0). Each of them is characterised by a different communication style.

Web 1.0 is a one-way communication model. The content posted on the website was published only with the participation of people from the IT industry. To post or edit individual texts on the Internet, it was necessary to have the appropriate qualifications, in particular, knowledge of programming languages such as HTML or JavaScript. The recipient of the content was passive, without the possibility of extending the content or reacting in any other way. The Web 1.0 model is thus similar to traditional communication channels such as radio, press or television.

From the year 1999-2003, user participation in publishing content on the Internet has changed dramatically. Usually referred to as Web 2.0., this stage of communication development had a significant impact on the social aspect even though it was associated with a relatively small technological breakthrough. It transposed the internet user from a passive recipient of content towards an active user with the opportunity to share their observations, experiences or exchange thoughts and ideas. Web 2.0 was a common space that appealed to the democratic nature of society because it gave each user a voice. This type of activity was carried out mainly by means of the USNET service, i.e. discussion groups arranged in a hierarchical structure gathering users interested in a given topic. In Poland, the first discussion group on the topic of saving lives, first aid, emergency services activities and tactics of rescue operations was a group called pl.misc. rescue, established on December 25, 1999, by Witold Andrzej Markow. Although this group was never officially closed, the exchange of information between users lasted till 2008.

In 2008, the concept of Web 3.0 entered the dictionary of IT specialists, which marks another transformation of the possibilities of user interaction within the Internet. A key feature of this stage is the use of semantic networks, artificial intelligence and three-dimensional graphics. Semantic Internet is an initiative postulating "representing data in formats that enable their automatic processing and integration, as well as an automatic inference based on them" [3]. Therefore, it is aimed at enabling access to the information contained on websites not only to users but also to autonomously operating algorithms. Such technical possibilities have provided more opportunities for the business use of the Internet, using e.g. entertainment space. Global social media uniting millions of users around the world, such as YouTube, Facebook or Twitter, began to emerge, and are now a very significant factor influencing the mood, opinions or views of the society. The information dissemination model has thus become more liberal, and the broadly understood society has become the actual creator of the message [4].

The number of social media users has been growing for many years, including Internet users from both developed and developing countries. For many people, social media has become synonymous with the Internet, as demonstrated in research by quartz.com. wykorzystaniem przez biznes, podmioty administracji rządowych oraz partie polityczne [2].

Od czasu podpisania traktatu z Maastricht, przestrzeń komunikacyjna w Internecie przechodzi nieustanną ewolucję poprzez rozwój poszczególnych etapów globalnej sieci (nazywanych umownie Web 1.0, 2.0, 3.0). Każdy z nich charakteryzuje się odmiennym sposobem komunikacji.

Web 1.0 to jednokierunkowy model komunikacji. Publikacja treści zamieszczanych na stronach WWW odbywała się wyłącznie przy udziale osób związanych z branżą teleinformatyczną. Do zamieszczania lub edytowania poszczególnych tekstów w Internecie niezbędne było posiadanie odpowiednich kwalifikacji, w szczególności znajomości języków programowania, takich jak HTML lub JavaScript. Odbiorca treści zajmował postawę bierną - bez możliwości rozszerzania treści czy też jakiejkolwiek innej reakcji. Model sieci Web 1.0 jest więc podobny do tradycyjnych kanałów komunikacyjnych, takich jak radio, prasa czy też telewizja.

W latach 1999-2003 udział użytkowników w publikacji treści w Internecie został diametralnie zmieniony. Web 2.0., bo tak nazwany został ten etap rozwoju komunikacji, choć wiąże się ze względnie niewielkim przełomem technologicznym, to miał jednak znaczny wpływ na aspekt społeczny. Przeobrażał on internautę z biernego odbiorcy treści w kierunku aktywnego użytkownika mającego możliwość dzielenia się swoimi spostrzeżeniami, doświadczeniami czy też wymianą myśli i idei. Web 2.0 stworzyła wspólną przestrzeń odwołującą się do demokratycznego charakteru społeczeństwa dzięki udzieleniu każdemu użytkownikowi prawa głosu. Tego typu aktywność realizowana była głównie za pomocą usługi USNET, czyli ułożonych w strukturę hierarchiczną grup dyskusyjnych skupiających użytkowników zainteresowanych daną tematyką. W Polsce pierwszą grupą dyskusyjną dotyczącą szeroko pojętego ratownictwa, udzielania pierwszej pomocy, działalności służb ratowniczych oraz taktyki działań ratowniczych była grupa o nazwie pl.misc.ratownictwo założona 25 grudnia 1999 r. przez Witolda Andrzeja Markowa. Choć grupa ta oficjalnie nie została zamknięta, to $w$ praktyce wymiana informacji pomiędzy użytkownikami trwała do $2008 \mathrm{r}$.

W 2008 r. do słownika specjalistów z dziedziny informatyki weszło pojęcie Web 3.0. Był to kolejny krok w kierunku zwiększania możliwości interakcji użytkowników w obrębie sieci Internet. Cechą charakterystyczną tego etapu jest wykorzystanie sieci semantycznych, sztucznej inteligencji oraz grafiki trójwymiarowej. Internet semantyczny to inicjatywa postulująca "reprezentowanie danych $w$ formatach umożliwiających ich automatyczne przetwarzanie i integrację, a także automatyczne wnioskowanie w oparciu o nie" [3]. Zatem ma on na celu umożliwienie dostępu do informacji zawartych na stronach internetowych nie tylko użytkownikom, ale i autonomicznie działającym algorytmom. Tego typu techniczne możliwości jeszcze szerzej otworzyły drogę do wykorzystania sieci Internet w celach biznesowych, m.in. w sferze rozrywki. Zaczęły powstawać ogólnoświatowe media społecznościowe zrzeszające miliony użytkowników na całym świecie, takie jak YouTube, Facebook czy Twitter. Są one obecnie bardzo znaczącym elementem wpływającym na nastroje, opinie czy też poglądy społeczeństwa. Model rozprzestrzeniania się informacji stał się zatem bardziej swobodny, a szeroko pojęte społeczeństwo stało się faktycznym kreatorem wiadomości [4]. 
In developing countries such as Indonesia, Nigeria, Brazil and India, $11 \%$ of Facebook users are unaware of the fact that they are using the Internet [5].

In Poland, the number of social media users is also increasing year by year. In 2014, 12 million Poles were registered, while in January 2019 this number increased to 18 million. It can therefore be assumed that almost every second Polish citizen is a social media user. The percentage of users on different social media platforms is shown in Table 1 [6].
Od wielu lat liczba użytkowników mediów społecznościowych wykazuje tendencję wzrostową. Obejmuje ona nie tylko Internautów zarówno w krajach rozwiniętych, jak i coraz częściej rozwijających się. Dla wielu osób media społecznościowe stały się tożsame z Internetem, co pokazują badania przeprowadzone przez quartz.com. W krajach rozwijających się: Indonezji, Nigerii, Brazylii oraz Indiach $11 \%$ użytkowników Facebooka nie zdaje sobie sprawy z faktu, że w istocie korzysta z sieci [5].

Również w Polsce z roku na rok zwiększa się liczba użytkowników mediów społecznościowych. W 2014 roku zarejestrowanych było 12 milionów Polaków, podczas gdy w styczniu 2019 roku liczba ta wzrosła do 18 milionów. Można zatem przyjąć, że prawie co drugi obywatel Polski jest użytkownikiem mediów społecznościowych. Udział procentowy użytkowników poszczególnych platform społecznościowych wśród ogólnej liczby osób korzystających z Internetu widoczny jest w tabeli 1 [6].

Table 1. The most popular social networking sites among Polish Internet users

Tabela 1. Najpopularniejsze serwisy społecznościowe wśród polskich użytkowników sieci Internet

No. / Lp. Social netwotking site / Nazwa serwisu społecznościowego
The percentage of Internet users using the platform / Odsetek użytkowników Internetu używających danej platformy [\%]

\begin{tabular}{|c|c|c|}
\hline 1 & YouTube & $92 \%$ \\
\hline 2 & Facebook & $89 \%$ \\
\hline 3 & Instagram & $55 \%$ \\
\hline 4 & Twitter & $35 \%$ \\
\hline 5 & Snapchat & $29 \%$ \\
\hline 6 & LinkedIn & $26 \%$ \\
\hline 7 & Pinterest & $25 \%$ \\
\hline 8 & nk.pl & $19 \%$ \\
\hline
\end{tabular}

Source: The authors' study based on Hootsuite \& We Are Social (2020), “Digital 2020 Poland”.

Źródło: Opracowanie własne na podstawie Hootsuite \& We Are Social (2020), „Digital 2020 Poland”.

The scientific literature offers several definitions of the term social media. A.M. Kaplan and M. Haenlein define social media as "a group of Internet-based applications that build on the ideological and technological foundations of Web 2.0 and that allow the creation and exchange of user-generated content" [7].

On the other hand, C.L. Hsu, S.J. Park and H.W Park define social media as "a set of platforms for daily communication where users share information and conduct discussions" [8]. M. Steenkamp, N. Hyde-Clarke, L. Safko and D.K. Brake claim that social media are "a set of platforms that enable and facilitate the creation and exchange of information using various forms of
Literatura naukowa przedstawia kilka definicji pojęcia media społecznościowe. A. M. Kaplan i M. Haenlein zdefiniowali je jako: "grupę internetowych aplikacji zbudowanych na ideowych i technologicznych podstawach sieci drugiej generacji (Web 2.0), które umożliwiają tworzenie i dzielenie się treściami generowanymi przez użytkowników" [7].

Z kolei C. L. Hsu, S. J. Park i H. W. Park przedstawiają media społecznościowe jako: „platformy do codziennej komunikacji, gdzie użytkownicy dzielą się informacjami i prowadzą dyskusje" [8]. M. Steenkamp i N. Hyde-Clarke oraz L. Safko i D. K. Brake twierdzą, że media społecznościowe to: „platformy umożliwiające oraz 
communication, e.g. words, images and videos" [9]. In Polish literature, this phenomenon is presented by M. Kampioni-Zawadka as "a set of platforms for activity and exchange of information and content between users that is based on interaction and expression of opinions and comments" [10].

The above definitions allow the conclusion that social media platforms (interchangeably referred to as social media and social networking sites) are means of communication which rely on new technologies and the Internet and are based on user involvement. They have a direct impact on social interactions and civic engagement, often causing their intensification or extinction [11].

Communication in social media in the context of security, in the opinion of the authors, should be perceived as the flow of information between organisations, social partners and the broadly understood environment. Increasingly, this aspect is noticed and used as an element of broadly understood citizens' security during a crisis.

Social media is characterized by the following factors [12]:

- possibility of using them on a large scale,

- original content can be permanently modified,

- social interaction propagates content,

- publications are created in an unforced manner,

- all elements resulting from co-authoring the content are not removed and are always accessible.

A great example illustrating the opportunities and threats in the process of communicating in a crisis using social media was the fire in Notre-Dame de Paris cathedral in Paris. Hence, in the following part of this paper the authors analysed the behaviour of Internet users in the context of the spread of information and the emergence of fake news about the aforementioned fire.

\section{Situational analysis}

The fire in April 2019, which consumed one of the most famous religious buildings, an architectural pearl of the Gothic style and one of the main symbols of Paris. It constitutes an important part of cultural heritage and is one of the most visited historial objects in Europe. Every year, 14 million tourists come to this place (for comparison, the Eiffel Tower has twice as lower frequency as the Cathedral) [13]. Therefore, the image of burning Notre-Dame shocked public opinion, not only French but also worldwide. It was yet another blow to the world heritage and culture, as only eight months earlier information had been received from Rio de Janeiro about the irretrievable losses incurred as fire destroyed Brazil's oldest National Museum. Such events not only echo widely among citizens around the world but also remind us of how devastating, ruthless and dangerous fire is - also for national treasures.

The information about the fire in Paris spread around the almost all developed countries in a split second. Numerous ułatwiające tworzenie i wymianę informacji przy użyciu różnych form przekazu, np.: słów, obrazów, filmów" [9]. W polskim piśmiennictwie zjawisko to prezentuje M. Kampioni-Zawadka - jako: „platformę aktywności i wymiany informacji oraz treści pomiędzy użytkownikami oparte na interakcji i wyrażaniu opinii oraz komentarzy" [10].

Powyższe definicje pozwalają wnioskować, że media społecznościowe (nazywane zamiennie platformami społecznościowymi oraz serwisami społecznościowymi) są środkami komunikacji opartymi na nowych technologiach, wykorzystującymi Internet i aktywność użytkowników. Mają one bezpośredni wpływ na interakcje społeczne, a także zaangażowanie obywatelskie, niejednokrotnie powodując ich intensyfikację lub wygaszanie [11].

W opinii autorów, odnoszenie się do komunikacji w mediach społecznościowych w kontekście bezpieczeństwa powinno być postrzegane jako przepływ informacji pomiędzy organizacjami, partnerami społecznymi oraz szeroko pojętym otoczeniem. Coraz częściej aspekt ten jest dostrzegany i wykorzystywany jako element całościowo rozumianego bezpieczeństwa obywateli podczas zdarzeń o charakterze kryzysowym.

Media społecznościowe cechują się następującymi czynnikami [12]:

- możliwość wykorzystania ich na dowolną skalę,

- pierwotna treść może być modyfikowana w permanentny sposób,

- interakcja społeczna powoduje rozprzestrzenianie się treści,

- publikacje powstają w sposób niewymuszony,

- wszystkie elementy będące wynikiem współtworzenia treści nie są usuwane i są stale dostępne.

Znakomitym przykładem obrazującym szanse i zagrożenia występujące w procesie komunikowania się w sytuacji kryzysowej przy wykorzystaniu mediów społecznościowych był pożar archikatedry Notre Dame. Stąd też, w niniejszym artykule, autorzy poddali analizie zachowania użytkowników Internetu w kontekście rozprzestrzeniania się informacji oraz pojawiania się fałszywych wiadomości na temat pożaru archikatedry.

\section{Analiza sytuacyjna}

W kwietniu 2019 roku w archikatedrze Notre Dame doszło do groźnego pożaru. Ta architektoniczna perła gotyku, a także jeden z głównych symboli Paryża, stanowi ważny element dziedzictwa kulturowego i jest jednym z częściej odwiedzanych zabytków Europy. Rokrocznie do tego miejsca przybywa 14 mln turystów (dla porównania wieża Eiffla cieszy się dwukrotnie mniejszą frekwencją) [13]. Dlatego też obrazy płonącej katedry wstrząsnęły opinią publiczną nie tylko we Francji, ale i na całym świecie. Warto przypomnieć, że kilka miesięcy wcześniej świat obiegła informacja o pożarze muzeum narodowego Rio de Janeiro. Znajdujące się tam eksponaty zostały bezpowrotnie pochłonięte przez żywioł, powodując niepowetowane straty dla dziedzictwa kulturowego świata. Wydarzenia te przypomniały opinii publicznej, a także ekspertom z dziedziny ochrony zabytków, o tym jak niebezpieczny i nieprzewidywalny jest żywioł ognia.

Doniesienia o trawiącym katedrę Notre Dame pożarze w szybkim tempie dotarły do niemal wszystkich krajów rozwiniętego 
comments in various types of mass media were highly emotional. Many commentators and general public from Western Europe saw the end of Christian culture, a sign of the times, in the image of the flames consuming the cathedral. However, Piotr Sikora accurately observes "not the element itself, but a great number of comments was seen as a sign from God" and that is a sign of the times [14]. These opinions and comments were articulated largely in the digital world, especially on social media.

The tragic fire of Notre-Dame broke out on Monday 15, April at $6.50 \mathrm{pm}$, though the first warnings flowing from the cathedral's fire alarm system were transmitted to the French firefighters half an hour earlier. High flames and clouds of thick smoke drew thousands of tourists and Parisians to the banks of the Seine river, where they could witness the fire devouring the roof of the building, as well as the collapse of the 93-meter spire.

In the discussed topic, it should be noted that most of the observers there were Internet users. We Are Social report states that among 65 million French citizens, as many as 60 million (92\%) are regular Internet users, and 38 million (58\%) actively use social media such as Facebook, Twitter, WhatsApp etc. Every second Frenchman uses a portable mobile device such as a smartphone or tablet, spending an average of 1 hour $17 \mathrm{~min}$ a day on following the news on social media [15]. During the fire, Internet users, who were also eyewitnesses, used social media live streaming software, which allowed other users to watch rescue and firefighting activities in real-time. Text content, photos and videos were published on various social media platforms. These live streams contributed to the dissemination of detailed information on ongoing rescue services activities among social media users from the entire world. Popularity of this topic in the Internet confirms the fact that in the first 13 hours after the fire, the video content was played by 35 million users, who reacted with comments and emoticons reflecting their emotions a total of over 80 million times. Reports from the action site on social media platforms conducted both by individual users who do not work in social journalism, as well as professional agencies media. Social networking platforms provided the latest news, photos and videos from the scene. The video transmission conducted by a Facebook account named Brut (global media company that creates short video content for audiences around the world and publishes content daily in three languages) was watched by 8 million users in the first 24 hours. It generated great interest among users, which can be visible in their reactions: 60 thousand comments, 102 thousand reactions through emoticons and 134 thous.

Another interesting example of a Facebook profile which broadcast the fire online is LADBible. The transmission conducted by the LADBible profile was slightly less popular, generating a total of 221 thousand reactions, but in this case, it is interesting to note that, on a daily basis, this profile provides users with popular but intellectually rather unrefined entertainment.

On Instagram, the most popular information was published by global and professional media like French Le Monde and British BBC News.

Also the reports made available through Twitter were not without significance. Twitter users most appreciated the video świata. Wiele komentarzy w różnego typu mediach masowych było nacechowanych dużym ładunkiem emocjonalnym. Komentatorzy, a za nimi znaczna część zachodniego społeczeństwa, doszukiwali się w pożarze symboliki kresu kultury chrześcijańskiej i swoistego znaku czasów. Piotr Sikora na łamach "Tygodnika Powszechnego" słusznie i trafnie zauważył, że "nie sam żywioł, a wielka liczba komentarzy interpretujących to wydarzenie jako znak od Boga" jest symbolem naszych czasów [14]. Komentarze i opinie, o których wspomniał Sikora, publikowane były w dużej mierze w świecie cyfrowym, w Internecie, z wykorzystaniem mediów społecznościowych na czele.

Tragiczny w skutkach pożar rozgorzał w poniedziałek 15 kwietnia 2019 roku o godzinie 18:50, choć pierwsze ostrzeżenia spływające $z$ systemu sygnalizacji pożaru katedry dotarły do francuskich strażaków pół godziny wcześniej. Szybko rozprzestrzeniający się ogień, wysokie płomienie, a także kłęby gęstego czarnego dymu unoszącego się nad budynkiem przyciągnęły rzesze mieszkańców Paryża oraz tysiące turystów nad brzeg Sekwany. Stali się oni naocznymi świadkami rozwijającego się pożaru, który minuta po minucie trawił poszycie dachu, doprowadzając do spektakularnego zawalenia się 93-metrowej iglicy.

W kontekście omawianego tematu istotnym faktem jest, że większość znajdujących się tam obserwatorów to statystycznie użytkownicy mediów społecznościowych i Internetu. Według raportu We Are Social spośród 65 milionów Francuzów aż 92\% z nich regularne korzysta z Internetu, a $58 \%$ jest aktywnymi użytkownikami mediów społecznościowych, takich jak Facebook, Twitter, WhatsApp itp. Połowa Francuzów do tego celu wykorzystuje urządzenia mobilne, takie jak smartfony czy też tablety. Statystyki pokazują, że średnio każdy Francuz spędza 1 godz. 17 min. dziennie na czytaniu oraz publikowaniu wiadomości w mediach społecznościowych [15]. Dlatego też w czasie pożaru użytkownicy, będący jednocześnie bezpośrednimi świadkami żywiołu, zaopatrzeni w podłączone do Internetu telefony komórkowe stali się społecznym dziennikarzami publikującymi w czasie rzeczywistym treści tekstowe, fotograficzne oraz wideo na różnych platformach społecznościowych. Relacje te przyczyniły się do rozpowszechniania szczegółowych informacji o prowadzonych działaniach ratowniczych wśród użytkowników mediów społecznościowych na całym świecie. O popularności tego tematu w przestrzeni Internetu może świadczyć fakt, iż w ciągu pierwszych 13 godzin od rozgorzenia pożaru publikowane $w$ mediach społecznościowych materiały wideo zostały odtworzone przez 35 milionów użytkowników. Wzbudzały emocje widoczne w komentarzach oraz reakcjach graficznych, których było w sumie przeszło $80 \mathrm{mln}$. Relacje z miejsca akcji prowadzili na platformach społecznościowych zarówno użytkownicy indywidualni na co dzień niezajmujący się tematyką dziennikarstwa społecznego, jak i profesjonalne agencje medialne. Facebookowy profil redakcji Brut (globalna firma medialna, która tworzy krótkie treści wideo dla odbiorców na całym świecie i publikuje treści codziennie w trzech językach) transmitował na żywo przekaz spod katedry Notre Dame. Został on obejrzany przez ponad $8 \mathrm{mln}$ użytkowników, co przełożyło się na ich cyfrowe reakcje: w sumie zostawili oni 102 tys. reakcji graficznych, 60 tys. komentarzy oraz 134 tys. udostępnień materiału na swoich profilach indywidualnych. 
material published by Patrick Galley, an AFP journalist - over 126 thousand comments, 120 thousand shares and 209 thousand reactions (and, in consequence, reached even more recipients).

Polish Internet users also showed significant interest in the Notre-Dame fire. This is evidenced by the sudden increase in the number of Google searches for the Notre-Dame (Google is the most popular service of this type). Figure 1 shows a timeline from April 10 to April 30 with two data marked: the search term Notre-Dame is marked in blue and, for comparison, the phrase TV program, which is relatively frequently searched by Internet users, is marked in red. The numbers in the chart represent individual queries relative to the highest point on the chart. The result is then scaled from 0 to 100 based on the topic proportionality in comparison to all searches of all themes. The value of 100 means the highest popularity of the phrase. A value of 50 means that the popularity of the phrase was twice as low. $A$ value of 0 indicates that the data is insufficient. The figure shows that between April 15 and April 17, the entry NotreDame was very often entered into the search engine, which shows the high interest in the subject. However, on April 18 this interest started to decrease [16].
Innym ciekawym przykładem profilu na platformie Facebook, który transmitował na żywo wydarzenia z pożaru, jest LADBible. To konto, które zasadniczo zajmuje się dostarczaniem użytkownikom Internetu popularnej i niezbyt wyrafinowanej intelektualnie rozrywki. Pomimo tego przekazywane przez ten profil informacje spotkały się z łącznie ponad 221 tys. reakcji użytkowników.

Warto wspomnieć, że profesjonalne, ogólnoświatowe marki medialne, takie jak francuski Le Monde czy też brytyjski BBC News, swoje transmisje internetowe realizowały głównie za pomocą innego serwisu społecznościowego - Instagramu.

Nie bez znaczenia były też relacje udostępnione za pomocą serwisu Twitter. Najbardziej popularnym źródłem informacji stał się profil Patryka Galleya z Agence France Press (AFP), a konkretnie zamieszczony przez reportera materiał wideo. Zyskał on ponad 126 tys. komentarzy, 209 tys. reakcji graficznych oraz 120 tys. udostępnień przez innych użytkowników Twittera (dzięki czemu trafił do jeszcze większej liczby odbiorców).

Polscy użytkownicy Internetu również wykazali duże zainteresowanie pożarem katedry Notre Dame. 0 fakcie tym świadczy gwałtowny wzrost zainteresowania hasłem Notre Dame w wyszukiwarce Internetowej Google będącej najpopularniejszym tego typu serwisem. Na ryc. 1 przedstawiono siatkę czasu w okresie od 10 do 30 kwietnia 2019 roku. Widoczne na niej dane przedstawiają częstość wyszukiwania hasła Notre Dame (kolor niebieski). W celach porównawczych przedstawiono także częstość wyszukiwania frazy program TV (kolor czerwony). Liczby na wykresie reprezentują stopień zainteresowania użytkowników w wyszukiwaniu względem najwyższego punktu na wykresie. Rezultat jest następnie skalowany w zakresie od 0 do 100 na podstawie proporcjonalności tematu względem wszystkich wyszukiwań wszystkich tematów. Wartość 100 oznacza najwyższą popularność hasła. Wartość 50 wskazuje, że popularność hasła była dwukrotnie mniejsza, natomiast wartość 0 oznacza brak wystarczających danych dla danego hasła. Na rycinie widać także, że $w$ dniach 15-17 kwietnia hasło Notre Dame było często wpisywane w wyszukiwarkę, co pokazuje wysokie zainteresowanie tym tematem, jednak już 18 kwietnia popularność zaczęła spadać [16].

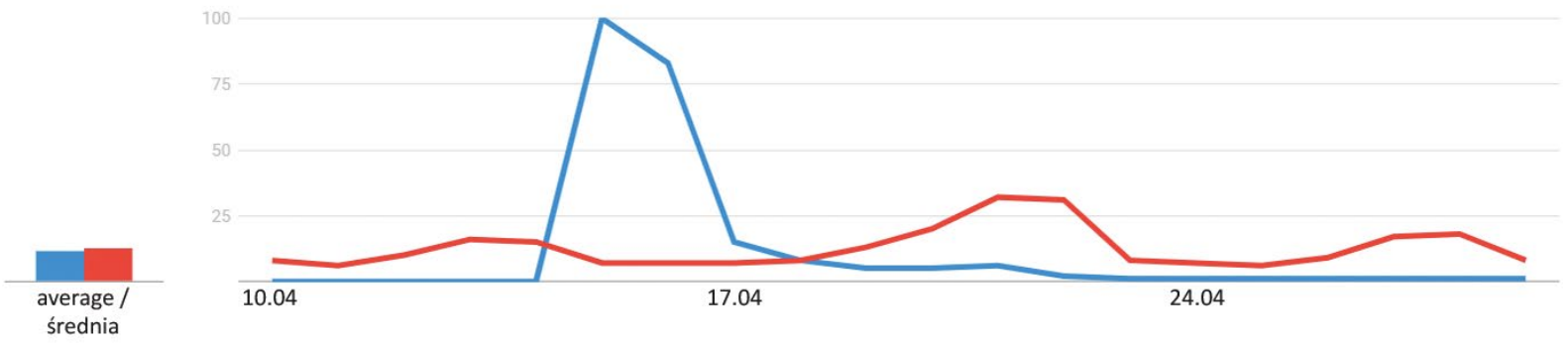

Figure 1. The timeline of the number of queries for the keywords Notre-Dame (blue) and TV Program (red) in the period 10-30 April 2019 Rycina 1. Popularność haseł Notre Dame (kolor niebieski) oraz Program TV (kolor czerwony) w wyszukiwarce internetowej Google w okresie 10-30 kwietnia 2019

Source: The authors' study based on data from Google Trends (https://trends.google.pl).

Źródło: Opracowanie własne na podstawie danych z Google Trends (https://trends.google.pl). 
Table 1. The most popular social networking sites among Polish Internet users

Tabela 1. Najpopularniejsze serwisy społecznościowe wśród polskich użytkowników sieci Internet

\begin{tabular}{|c|c|c|}
\hline No./ Lp. & Keyword / Hasło & Percentage change / Zmiana procentowa \\
\hline 1 & Notre Dame Cathedral in Paris / Katedra Notre Dame w Paryżu & $>5000 \%$ \\
\hline 2 & Cathedral / Katedra & $2800 \%$ \\
\hline 3 & Fire / Pożar & $800 \%$ \\
\hline 4 & Paris / Paryż & $600 \%$ \\
\hline 5 & Exam / Egzamin & $250 \%$ \\
\hline 6 & Games of Thrones / Gra o tron & $200 \%$ \\
\hline 7 & HBO & $170 \%$ \\
\hline 8 & Mass / Msza & $160 \%$ \\
\hline 9 & HBO GO & $140 \%$ \\
\hline 10 & Marathon race / Bieg maratoński & $120 \%$ \\
\hline
\end{tabular}

Source: The authors' study based on Hootsuite \& We Are Social (2020), "Digital 2020 Poland".

Źródło: Opracowanie własne na podstawie Hootsuite \& We Are Social (2020), „Digital 2020 Poland”.

Great interest in the subject of the Notre-Dame fire in social media was provoked by the appearance of the so-called fake news, which PWN Dictionary of Polish Language defines as "false news, most often disseminated by tabloids to cause sensation, defame someone (usually politics)". Fake news circulate primarily on social media, misleading the public. The problem with fake news circulating on the Internet is that it can change the attitudes, reactions and behaviours of society. From the perspective of those responsible for public security, fake news can also contribute to the misallocation of resources during adverse events, such as terrorist attacks and natural disasters [17]. An analysis performed by Vosoughi et al. of several hundred verified true and false rumours on Twitter confirms that fake news spreads faster and more widely than real news [19]. The reason for this is, among others, the fact that these messages are highly emotional and therefore draw the attention of end-users in a highly effective manner [18]. In the case of Notre-Dame, several dangerous fake news appeared in the first few hours, introducing to the discussion, among others, racist narrative. They could provoke secondary threats. One of the sources of information manipulation was a Twitter entry by Christopher J. Hale - a famous American politician and columnist for Time magazine. He wrote: "A Jesuit friend in Paris who works in \#NotreDame told me cathedral staff said the fire was intentionally set." This message was distributed among several thousand users within 10 minutes, despite the fact that its author removed it and wrote a disclaimer just a moment after publication. A few days later,
Popularność relacji i doniesień z pożaru katedry Notre Dame w mediach społecznościowych spowodowała generowanie tzw. fake newsów. Według Słownika Języka Polskiego PWN pojęcie to definiowane jest jako „nieprawdziwe, fałszywe wiadomości, najczęściej rozpowszechniane przez tabloidy w celu wywołania sensacji, bądź zniesławienia kogoś (najczęściej polityka)". Fake newsy propagowane są w dużej mierze w mediach społecznościowych w celu wprowadzenia opinię publiczną w błąd. Krążące w Internecie fałszywe wiadomości niosą ze sobą ryzyko zmiany postaw, zachowań, a także reakcji społeczeństwa na dane zjawisko lub wydarzenie. Z perspektywy osób i instytucji odpowiedzialnych za bezpieczeństwo tego typu nieprawdziwe informacje, w skrajnych przypadkach, mogą spowodować m.in. niewłaściwą alokację zasobów ratowniczych podczas zdarzeń niepożądanych, takich jak ataki terrorystyczne i klęski żywiołowe [17]. Fałszywe informacje rozprzestrzeniają się szybciej i docierają do większego grona odbiorców niż informacje prawdziwe, o czym świadczy szeroka analiza prawdziwych informacji i plotek w serwisie Twitter przeprowadzona przez Vosoughi i in. [19]. Badania te potwierdziły, że komunikaty fałszywe $w$ dużym stopniu nacechowane są emocjonalnie, co zwiększa zainteresowanie i skupia uwagę użytkowników końcowych [18]. W przypadku pożaru katedry Notre Dame w ciągu pierwszych godzin pojawiło się kilkanaście rozpropagowanych na dużą skalę fałszywych wiadomości mogących powodować zagrożenia wtórne. Szczególnie niebezpieczne były te wprowadzające do dyskusji publicznej m.in. narrację rasistowską. Wśród wielu źródeł manipulacji informacją charakterystyczny był wpis w serwisie 
Hale told buzzfeednews.com: "For the record, I completely believe [the fire] was an accident. The Jesuit who texted me - my friend - believes it was an accident" [19].

On the other hand, short, low-resolution video material has gained infamy on Facebook. The video shows a figure walking on the facade of the building. The low quality of the recording did not make it possible to clearly identify the person, which resulted in the emergence of conspiracy theories describing the character as "Muslim". According to some users the headdress looked like a turban. A few hours later, the same video in better quality hit the web. As it turned out, a video recorded by the American television station CNBC showed a firefighter with a helmet on his head, putting out the fire. A detailed image in low and high resolution can be seen in figure 2 [20].
Twitter Christophera J. Hale'a - znanego amerykańskiego polityka i felietonisty współpracującego m.in. z opiniotwórczym magazynem "Time". Na swoim profilu opublikował on taką wiadomość: „Jezuicki przyjaciel z Paryża, który pracuje w Notre Dame, powiedział mi, że personel katedry uważa, jakoby pożar był zamierzony". Oświadczenie to w ciągu 10 minut zostało rozpowszechnione wśród kilku tysięcy użytkowników, choć autor w chwilę po publikacji napisał dementi. Hale kilka dni po tym fakcie udzielił wywiadu dla serwisu buzzfeednews.com. Stwierdził tam: „całkowicie wierzę, że pożar był wypadkiem. Jezuita, który do mnie napisał - mój przyjaciel - także uważa, że to był wypadek" [19].

Z kolei w serwisie Facebook popularność zyskał krótki film wideo charakteryzujący się niską rozdzielczością. Widać w nim było postać chodzącą po fasadzie budynku. Brak widocznych szczegółów na nagraniu nie pozwolił jednoznacznie określić, kim była osoba widoczna na filmie. Spowodowało to pojawienie się teorii spiskowych identyfikujących ową postać jako muzułmanina, o czym świadczyć miało - według części użytkowników nakrycie głowy przypominające wyglądem turban. W przeciągu następnych kilku godzin media społecznościowe obiegł ten sam film, jednak w lepszej jakości. W rzeczywistości oryginalny materiał autorstwa amerykańskiej stacji telewizyjnej CNBC przedstawiał funkcjonariusza paryskiej straży pożarnej z hełmem na głowie podczas rozpoznania sytuacji. Szczegółowy obraz w niskiej oraz w wysokiej rozdzielczości przedstawia rycina 2 [20].

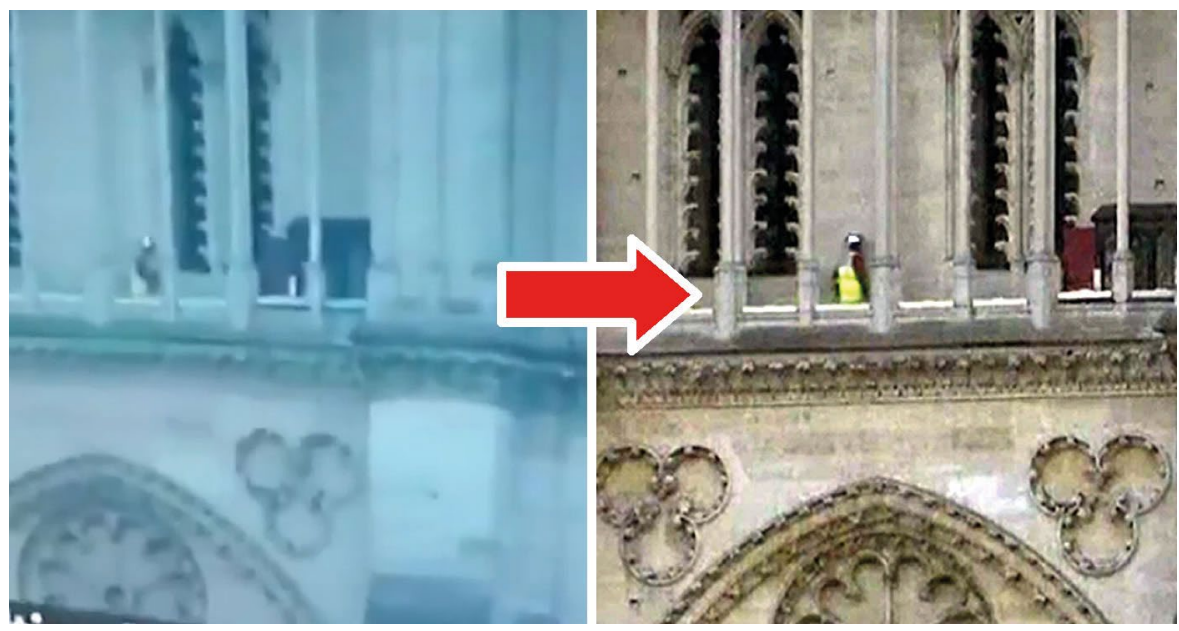

Figure 2. Low resolution (left) and high resolution (right) video of fake news during the fire of Notre-Dame Cathedral

Rycina 2. Materiał wideo niskiej (po lewej) i wysokiej (po prawej) rozdzielczości będący źródłem fałszywych wiadomości podczas pożaru katedry Notre Dame

Source: https://www.mimikama.at/allgemein/video-mann-auf-notre-dame/ [accessed: 08.08.2019]

Źródło: https://www.mimikama.at/allgemein/video-mann-auf-notre-dame/ [dostęp: 08.08.2019].

Another example that will be discussed is the story of two architecture students who, witnessing the cathedral fire, became the target of the hate speech of thousands of Facebook and other social media users. They were photographed with a smile on their faces while the Paris cathedral was burning in the background. Around 8 p.m., the policemen ordered the observers standing on the Seine bank to leave the security border. When the
Kolejny przykład warty omówienia to historia dwóch paryskich studentów architektury. Będąc bezpośrednimi świadkami pożaru, stali się oni obiektem mowy nienawiści zarówno wielu tysięcy użytkowników Facebooka, jak i pozostałych mediów społecznościowych. Powodem takiej sytuacji była opublikowana fotografia tych mężczyzn z uśmiechem na twarzach w czasie, gdy katedra Notre Dame płonęła w tle. Wspomniani studenci, obserwując trawiący 
aforementioned students walked under the red and white safety tape, a photo was taken of them, contributing to their future problems. Originally, the photo was posted without a caption or comment on Sputnik France's Facebook profile at 10:37 p.m. and was shared a few minutes later by far-right sites in France and the US. "Muslims laugh as blaze destroys Notre Dame cathedral during Holy Week", wrote far-right American journalist Pamela Geller at 10:45 p.m. Soon after, the French-language Infos-Israel. News Facebook page published an article entitled "Allah is Great: Muslims Laugh at the Fire of Notre-Dame". Within hours, the photo spread across social media, including forums like Reddit and 4Chan. Many Internet users have accused students of being happy at the sight of the tragedy. In comment sections, racist and Islamophobic insults included, inter alia, death threats by lynching [21]. Because the photo quickly circulated on Facebook and other social media networking sites, Sputnik France published an article emphasizing that at no time did any of the editorial staff suggest that these two people were Muslim and were laughing because of the fire. The news agency was surprised that some users found it appropriate to speculate on the religious beliefs of these two men solely on the basis of their appearance [22]. The controversial photo - presented in Figure 3 - has been thoroughly analysed by many organisations fighting disinformation on social media, such as Politifact [23], Nieuwscheckers.nl [24], or Fact Check AFP [25].

The photograph was initially considered to be fake, but finally, it turned out to be true - however, the smile of the students was caused by the fact that one of them had been caught in the safety tape surrounding the zone a moment earlier [25].

Another example of cybercriminal activities was an attempt to extort money from social media users who had been agitated by the cathedral fire. While hundreds of firefighters in Paris were fighting the element, suspicious and fraudulent donations began popping up on social media to help rebuild Notre-Dame. "We see a spike in fake online donation drives after every tragedy or natural disaster. It's disgusting people try to take advantage of human kindness and our desire to help during a difficult time," said Mark Brnovich, Arizona Attorney General via his website. "While giving to important causes is commendable, Arizonans need to do their homework before they donate to any charity" [26].

This type of cybercriminal activity is nothing new, but the technical underpinnings of the Internet and its social media platforms allow hackers and spammers to scale their efforts at an unprecedented rate. A group of Internet crime specialists from ZeroFOX have listed the Internet crime attempts related to the Notre-Dame fire:

- enticing users to click on spam links - seemingly related to charity -that generate advertising revenue,

- enticing users to donate money through fraudulent pages, some of which may be imitating charity organizations or websites,

- enticing users to click on fraudulent charity-related links that download malware,

- enticing users to invest in scams that promise future high stock-payouts related to rebuilding, also known as stock fraud. budynek żywioł z relatywnie bliskiej odległości, zostali skierowani przez zabezpieczających teren policjantów poza strefę określającą granicę bezpieczeństwa. Gdy przechodzili oni pod czerwono-białą taśmą bezpieczeństwa zrobiono im zdjęcie będące przyczynkiem do ich przyszłych problemów. Fotografia została opublikowana bez stosownego komentarza oraz jakiegokolwiek podpisu na profilu Sputnik France w serwisie Facebook o godz. 21:37. W kilka minut zostało rozpropagowane przez skrajnie prawicowe organizacje we Francji i USA wśród swoich zwolenników. Jedną z reakcji na tę fotografię był komentarz amerykańskiej dziennikarki Pameli Geller, która o godz. 22:45 na swoim koncie napisała: „Muzutmanie śmieją się, gdy ogień niszczy katedrę Notre Dame podczas Wielkiego Tygodnia". Kilkanaście minut później Infos-Israel. News w języku francuskim opublikował artykuł o znamiennym tytule: „Allah jest wielki: muzułmanie śmieją się na widok ognia Notre-Dame". W ciągu kolejnych kilku godzin fotografia została rozpropagowana na dziesiątkach kont w mediach społecznościowych, w tym także na forach Reddit i 4Chan skupiających przeciwników migracji uchodźców do Europy. Użytkownicy Internetu oskarżali studentów o radość, jaką ci wyrażali na widok tragedii Notre Dame. W sekcjach komentarzy islamofobiczne i rasistowskie obelgi zawierały groźby karalne, takie jak śmierć przez samosąd [21]. W związku z tym, że zdjęcie w bardzo szybkim tempie trafiło do tysięcy użytkowników serwisu Facebook, redakcja Sputnik France opublikowała oświadczenie podkreślające, że nikt z jej członków nie sugerował, aby studenci byli praktykującymi muzułmanami śmiejącymi się z faktu wybuchu pożaru. Dziennikarze Sputnika byli zaskoczeni faktem, że część użytkowników uważa za stosowne spekulować na temat poglądów religijnych i światopoglądowych tych dwóch mężczyzn wyłącznie na podstawie ich wyglądu [22]. Kontrowersyjne zdjęcie - przedstawione na rycinie 3 - zostało poddane analizie przez kilka organizacji zwalczających dezinformację w Internecie, takich jak: Nieuwscheckers.nl [zob. 23], Politifact [zob. 24], czy też Fact Check AFP [25].

Choć obraz ten początkowo uznany został za spreparowany, to jednak ostatecznie okazał się prawdziwy. Jednak kontekst uśmiechu studentów spowodowany był faktem, że jeden z nich w chwilę wcześniej zaplątał się o zabezpieczającą strefę pożaru taśmę bezpieczeństwa [25].

W kontekście omawianego tematu warto zwrócić uwagę na aktywność cyberprzestępców poprzez próby wyłudzenia pieniędzy od użytkowników mediów społecznościowych poruszonych pożarem katedry. Podczas gdy w Paryżu setki strażaków walczyły z ogniem trawiącym budynek, w mediach społecznościowych zaczęły pojawiać się podejrzane i oszukańcze zbiórki datków na pomoc w odbudowie Notre Dame. „Obserwujemy wzrost liczby fałszywych darowizn online po każdej tragedii lub klęsce żywiołowej. Przestępcy próbują wykorzystać ludzką życzliwość i naszą chęć do pomocy w trudnych chwilach" - przekazał za pośrednictwem strony internetowej Mark Brnovich, prokurator generalny stanu Arizona - „Chociaż udzielanie pomocy na ważne cele jest godne pochwały, mieszkańcy Arizony muszą zachować czujność, zanim przekażą darowiznę na jakąkolwiek organizację charytatywną" [26].

Tego typu działania cyberprzestępców nie są niczym nowym, ale techniczne strony zarówno Internetu, jak i poszczególnych platform mediów społecznościowych pozwalają hakerom i spamerom 
For the above purposes, cybercriminals used the following tactics and techniques:

- using bots on Twitter to spread donation links leading to spam or malware sites,

- impersonating websites and social media accounts of legitimate charity organizations,

- sending fraudulent charity emails with bad links or attachments,

- registering domains related to the disaster,

- creating fake donation campaigns on crowdfunding sites [27].

Governments of particular countries as well as the largest companies in the social media industry have been trying to fight manipulation and disinformation on their platforms for several years. Algorithms are responsible for most of the content filtering activities and they are improved over time. Thus, in the case of the Notre-Dame fire, the YouTube algorithm, which is designed to protect users from fake news and misleading videos, caused confusion. Under the video footage of the fire by France 24, you could find automatically posted information about the terrorist attacks of September 11, 2001, in New York. The two towers above NotreDame were misidentified by the YouTube algorithm and treated as the twin towers of the World Trade Center. The image recognition function, in this case, was counterproductive [28].

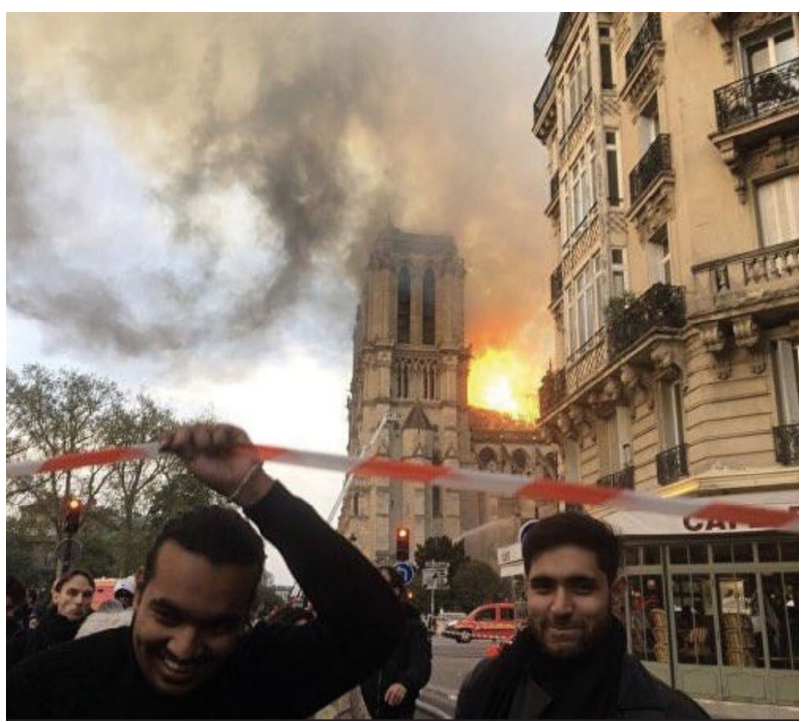

na zwiększanie osiągania zysków w bezprecedensowym tempie. Grupa specjalistów zajmujących się przestępstwami internetowymi z firmy ZeroFOX wyszczególniła próby przestępstw internetowych związanych z pożarem Katedry Notre Dame:

- zachęcanie użytkowników do klikania w fałszywe odnośniki - pozornie związane z organizacjami charytatywnymi, ale w rzeczywistości generujące przychody z reklam,

- apelowanie o przekazywanie pieniędzy za pośrednictwem fałszywych witryn imitujących oryginalne strony internetowe organizacji charytatywnych,

- inicjowanie do klikania w fałszywe oprogramowanie organizacji charytatywnych, które infekują komputery użytkowników złośliwym oprogramowaniem,

- zachęcanie do inwestowania środków finansowych w wysoko oprocentowaną pożyczkę w działania związane $z$ odbudową katedry.

W powyższych celach cyberprzestępcy stosowali następujące taktyki:

- używanie autonomicznych algorytmów (botów) na platformie Twitter,

- tworzenie fałszywych stron internetowych i kont w mediach społecznościowych imitujących legalnie działające organizacje charytatywne,

- masowe wysyłanie fałszywych e-maili o charakterze charytatywnym z fałszywymi odnośnikami lub załącznikami,

- rejestracja domen związanych z pożarem,

- tworzenie fałszywych kampanii darowizn w witrynach finansowania społecznego (crowdfunding) [27].

Rządy poszczególnych państw na równi z największymi firmami branży mediów społecznościowych od kilku lat usiłują walczyć z dezinformacją i manipulacją w Internecie. Od strony technicznej znaczną część działań związanych z filtrowaniem treści przeprowadzają autonomiczne algorytmy. Choć raz na jakiś czas można spotkać się z ich wadliwym działaniem, to z roku na rok są udoskonalane i dostosowywane do nowych technik cyberprzestępców. I tak w przypadku omawianego tematu zawiódł algorytm odpowiadający za wydanie ostrzeżeń o fałszywej treści w serwisie YouTube. Program ten z założenia ma chronić użytkowników przed nieprawdziwymi lub zmanipulowanymi filmami, a także wprowadzającymi w błąd wiadomościami. Jednak podczas pożaru Notre Dame sam spowodował dezinformację, gdyż opatrzył materiał wideo palącej się Katedry (opublikowany przez France 24) automatyczną informacją o historii ataków terrorystycznych z 11 września 2001 r. w Nowym Jorku. Algorytm YouTube pomylił dwie płonące wieże wznoszące się nad Notre Dame z bliźniaczymi wieżami World Trade Center. Funkcja mająca na celu rozpoznanie obrazu, w tym przypadku nie przyniosła oczekiwanego efektu [28].

Figure 3. French students leaving the safety zone

Rycina 3. Francuscy studenci podczas opuszczania strefy bezpieczeństwa.

Source/Źródło: https://sptnkne.ws/mnq7 [dostęp/accessed: 08.08.2020]. 
The agitation of the whole world connected with the fire caused an avalanche of comments from politicians from many countries. The communication was carried out mostly through official social media channels, with Twitter taking the leading role. Polish politicians also published their reactions. President of the Republic of Poland Andrzej Duda said "In March Saint-Sulpice, today NotreDame. A tragedy for believers, a catastrophe for the world cultural heritage and art. Probably poignant for everyone ..." Prime Minister Mateusz Morawiecki wrote: "The \#NotreDame cathedral on fire is a huge misfortune for the Church and European history. It is a tragic moment for all Catholics, Christians and lovers of great works of art that we will lose forever. Tonight our thoughts go out to Paris, France ..."

Twitter has also become a tool for discussion at a level unimaginable outside the world of social media. The President of the United States wrote in a public message on Twitter, "So horrible to watch the massive fire at Notre Dame Cathedral in Paris. Perhaps flying water tankers could be used to put it out. Must act quickly!" This statement was widely criticized by many firefighting specialists from many countries [31].

\section{Conclusions}

This paper is an assessment of the problem of the role and the potential of social media in a crisis, in this case, a fire. The number of Internet users, as well as social media users, which has been growing for over a dozen years, indicates that it makes sense to use social media as a tool, on the one hand, for providing current information about a crisis, and, on the other hand, for obtaining data which may be important when planning and implementing rescue and aid measures. This is due to a key feature of social media which is a two-way communication style and interaction between the sender and recipient of the information. Another important aspect is the use of mechanisms and algorithms that automatically collect data on user activity, such as location and its change at a specific time and place. The data - used on a daily basis to generate profits by social media platforms - during a crisis can be implemented by the fire brigade and emergency services to ensure the most effective disposition and management of forces and resources on the spot. This state of affairs shows that the role of using social media in a crisis is developmental and will probably be used to an increasing extent also in the case of fires and other threats to cultural heritage.
Poruszenie całego świata w obliczu trwającej tragedii spowodowało lawinę komentarzy polityków z wielu krajów. Komunikacja ta była prowadzona m.in. poprzez oficjalne kanały w mediach społecznościowych, z których wiodącą rolę zajął serwis Twitter. Swoją reakcję opublikowali polscy politycy - Prezydent RP Andrzej Duda: „W marcu Saint-Sulpice, dziś Katedra Notre Dame. Tragedia dla ludzi wierzących, katastrofa dla światowej kultury i sztuki. Przejmujące chyba dla wszystkich...” oraz Prezes Rady Ministrów Mateusz Morawiecki: „Katedra \#NotreDame w ogniu jest ogromnym dramatem dla Kościoła i europejskiej historii. To tragiczna chwila dla wszystkich katolików, chrześcijan oraz miłośników wielkich dzieł sztuki, które stracimy bezpowrotnie. Polska łączy się w tej chwili myślami z Paryżem, z Francją...".

Twitter stał się także polem do dyskusji, jakiej nie sposób sobie wyobrazić na takim szczeblu władzy poza światem mediów społecznościowych. Prezydent Stanów Zjednoczonych w publicznej wiadomości w serwisie Twitter napisał: „To straszne, gdy patrzy się na ogromny pożar w katedrze Notre Dame w Paryżu. Być może można by go zgasić samolotami gaśniczymi. Musicie działać szybko!". Wypowiedź ta spotkała się z szeroką krytyką wielu specjalistów z dziedziny pożarnictwa z wielu krajów [31] .

\section{Konkluzje}

Niniejszy artykuł jest analizą problemu związanego z rolą i potencjałem serwisów społecznościowych w sytuacjach kryzysowych, do których niewątpliwie zalicza się pożar. Stale zwiększająca się liczba użytkowników Internetu i - w konsekwencji - mediów społecznościowych wiąże się z możliwością coraz szerszego wykorzystania tego narzędzia do przekazywania bieżących informacji o sytuacji kryzysowej, a także pozyskiwania danych przydatnych w planowaniu i realizacji działań z zakresu szeroko pojętego bezpieczeństwa - w tym działań ratowniczych i pomocniczych. Sprzyja temu m.in. cechy charakterystycznej mediów społecznościowych - możliwości prowadzenia obustronnej komunikacji i interakcji pomiędzy nadawcą i odbiorcami. Drugą istotną płaszczyzną jest stosowanie autonomicznych algorytmów i mechanizmów zbierających dane o aktywności poszczególnych użytkowników, w tym lokalizacji oraz jej zmiany w określonym czasie. Informacje te - eksploatowane przez platformy społecznościowe w celu generowania zysków - podczas sytuacji kryzysowych mogą zostać łatwo zaimplementowane przez służby ratunkowe do optymalizacji dysponowania i zarządzania siłami i środkami w miejscu prowadzonych działań ratowniczych. Taka perspektywa pokazuje, że rola mediów społecznościowych w sytuacjach kryzysowych nie jest zamknięta, a wręcz przeciwnie - jest rozwojowa. Można spodziewać się, że z biegiem czasu ten środek komunikacji będzie wykorzystywany w coraz szerszym zakresie, także w przypadkach takich jak pożary i inne zagrożenia dla dóbr kultury. 


\section{Literature / Literatura}

[1] Traktat o Unii Europejskiej. Maastricht.1992.02.07 (Dz. U. 2004.90.864/30).

[2] Sarowski Ł., Od Internetu Web 1.0 do Internetu Web 4.0 - ewolucja form przestrzeni komunikacyjnych w globalnej sieci, „Rozprawy Społeczne” 2017,11, 1, 32-39.

[3] Walkowska J., Jeśli nie Web 2.0, to co?, „Biuletyn EBIB” 2012, 2(129), http://www.nowyebib.info/images/stories/ numery/129/129_walkowska.pdf [dostęp: 10.03.2020].

[4] Neuberger Ch., Wandel der aktuellen Öffentlichkeit im Internet. Gutachten für den Deutschen Bundestag. Vorgelegt dem Büro für Technikfolgen-Abschätzung beim Bundestag, WWU Munster 2004, 3, 65-74.

[5] Marini L. Millions of Facebook users have no idea they're using the internet, https://qz.com/333313/milliions-of-facebook-users-have-no-idea-theyre-using-the-internet/ [dostęp: 19.07.2020].

[6] Raport Hootsuite \& We Are Social (2020), „Digital 2020 Poland", https://datareportal.com/reports/digital-2019-global-digital-overview [dostęp: 30.07.2020].

[7] Kaplan A., Haenlein M., Users of the world, unite! The challenges and opportunities of social media, "Business Horizons" 2010, 53, 59-68, https://doi.org/10.1016/j. bushor.2009.09.003.

[8] Hsu C. L., Park S. J., Park H.W., Political discourse among key Twitter users: the case of Sejong city in South Korea, "Journal of Contemporary Eastern Asia" 2013, 12, 1, 65-79, https://doi.org/10.17477/jcea.2013.12.1.065.

[9] Safko L., Brake D. K., The Social Media Bible: Tactics, Tools and Strategies for Business Success, John Wiley \& Sons, Hoboken, New Jersey 2009.

[10] Kampioni-Zawadka M., Wykorzystanie mediów społecznościowych w rekrutacji pracowników i ich wpływ na budowanie wizerunku atrakcyjnego pracodawcy, "Studia Oeconomica Posnaniensia" 2014, 2, 9, 61-80.

[11] Brandtzæg P. B., Heim J., A typology of social networking sites users, "International Journal of Web Based Communities" 2011, 7(1), 28-51, https://doi.org/10.1504/ IJWBC.2011.038124.

[12] Joshi A., Web 2.0 Mining: Analyzing Social Media, w. Proceedings of the NSF, Symposium of Next Generation of Data Mining and Cyber-Enabled Discovery for Innovation, 2007, https://ebiquity. umbc.edu/paper/html/id/374 [dostęp: 16.10.2020].

[13] Domagalska P., Katedra Notre Dame się sypie. Kościół zbiera $100 \mathrm{mln}$ euro na konserwację. Celują w Amerykanów, przypominają film Disneya, wyborcza.pl, https://wyborcza. $\mathrm{pl} / 7,75410,22302972$,kosciol-we-francji-chce-zebrac-100-mln-euro-na-konserwacje-katedry.html [dostęp: 15.06.2020].

[14] Sikora P., Boże znaki, „Tygodnik Powszechny” 2019, 19, 12-15.

[15] Raport We Are Social 2019, https://wearesocial.com/global-digital-report-2019 [dostęp: 10.08.2019].

[16] Ludovic M., How could we rejoice in the Notre-Dame fire? Two victims of online hate share their story, https://factcheck.afp.com/how-could-we-rejoice-notre-dame-fire-two-victims-online-hate-share-their-story [dostęp: 10.08.2019].
[17] Lytvynenko J., Silverman C., A Timeline Of How The Notre Dame Fire Was Turned Into An Anti-Muslim Narrative, https://www.buzzfeednews.com/article/janelytvynenko/ notre-dame-hoax-timeline [dostęp: 10.08.2019].

[18] Demczuk A., Fenomen ruchu antyszczepionkowego, czyli fake news i postprawda na usługach hipotezy A. Wakefielda, "Annales Universitatis Paedagogicae Cracoviensis Studia de Cultura" 2018, 10(4), 92-113, https://doi. org/10.24917/20837275.10.4.8.

[19] Vosoughi S., Roy D., Aral S., The spread of true and false news online, "Science" 2018, 359, 6380, 1146-1151, https://doi.org/10.1126/science.aap9559.

[20] Betanzos M., Algunas fake news sobre Notre Dame, https:// spondeomedia.com/algunas-fake-news-sobre-notre-dame/ [dostęp: 10.08.2019].

[21] Banet R., How could we rejoice in the Notre-Dame fire? Two victims of online hate share their story, https://factcheck. afp.com/how-could-we-rejoice-notre-dame-fire-two-victims-online-hate-share-their-story [dostęp: 10.08.2019].

[22] Oh, the Irony: Fake Watchers Make False Claim About Sputnik's 'Fake News', sputniknews.com, https://sptnkne.ws/ mnq7 [dostęp: 10.08.2019].

[23] Burger P., Politifact noemt Sputnik-foto Notre Dame ten onrechte vals, pobrane $\mathrm{z}$ : https://nieuwscheckers.nl/nieuwscheckers/politifact-noemt-sputnik-foto-notre-dame-ten-onrechte-vals/.

[24] O'Rourke C., Muslims laughing at Notre Dame and fact-checking photos in the era of false news, Polifact, pobrane z: https://www. politifact.com/facebook-fact-checks/article/2019/may/28/ muslims-laughing-notre-dame-and-fact-checking-phot/.

[25] Kosowski B., Luzar A., Media społecznościowe jako źródło informacji i dezinformacji na przykładzie pożaru katedry Notre Dame, w: Ochrona dóbr kultury na wypadek szczególnych zagrożeń: nowoczesne technologie w ochronie dziedzictwa: materiały konferencyjne, J. Giełżecki (red.), Wydawnictwo Szkoły Aspirantów Państwowej Straży Pożarnej, Kraków 2019, 131-135.

[26] Komunikat Attoyney General State of Arizona, Scam alert: Avoid Donation Scams After Notre Dame Cathedral Fire, https:// www.azag.gov/press-release/scam-alert-avoid-donation-scams-after-notre-dame-cathedral-fire [dostęp: 10.08.2020].

[27] Fraudsters Exploiting the Notre Dame Tragedy, ZeroFOX Alpha Team https://www.zerofox.com/blog/notre-dame-fire-social-media-scams/ [dostęp: 15.06.2020].

[28] YouTube wertet Videos zu Brand in Notre Dame als Fake News, diepresse.com, https://diepresse.com/home/techscience/5613473/YouTube-wertet-Videos-zu-Brand-in-Notre-Dame-als-Fake-News [dostęp: 10.03.2020].

[29] Cybulska J., Media jako uczestnik akcji ratowniczej, BITP Vol. 16 Issue 4, 2009, pp. 35-44.

[30] Schroeder M., Osoby izjawiska towarzyszące akcji ratowniczej, Szkoła Aspirantów PSP w Poznaniu, Poznań 2002, 29.

[31] Experts deride Trump's Notre Dame firefighting advice as 'risible, theguardian.com, https://www.theguardian.com/ us-news/2019/apr/16/trump-notre-dame-twitter-advice-experts-deride-presidents-flying-water-tips [dostęp: 20.07.2020]. 
BOGDAN KOSOWSKI, D.SC. ENG. - professor at the Jagiellonian University, fire officer. Graduate of the Kraków Uniwersity of Technology (Eng.), the Main School of Fire Service (fire officer, since 1996 fire safety expert) and the AGH University of Science and Technology in Kraków, the Faculty of Management and Marketing (M.A., Manager in Mining). From 2005 to 2007 he participated in monthly seminars on the Development of the Theory and Practice of Management Sciences, organised by the "Orgmasz" Institute of Organisation and Management in Industry in Warsaw. He received his Ph.D. degree in 2000, at the Faculty of Mining, AGH University of Science and Technology, in the discipline of mining, speciality: management and marketing. In 2013, he received his postdoctoral degree at the Faculty of National Security of the National Defence University of Warsaw in the discipline of safety science. He was, among others: Deputy Voivodeship Commander of the State Fire Service in Katowice, Director of the Crisis Management Department in the Voivodeship Office in Katowice, and Vice-Chancellor and Deputy Commander at the Main School of Fire Service in Warsaw.

CPT. ARTUR LUZAR, M.SC. ENG. - State Fire Service officer, civil security engineer. He performs service at the Department of Information Technology and Communications of the Fire Service College of the State Fire Service in Kraków, conducting classes in the field of computer-assisted rescue actions. In his scientific work, he focuses on the role of social media in the widely understood domain of citizens' security.
DR HAB. INŻ. BOGDAN KOSOWSKI - profesor nadzwyczajny UJ, oficer pożarnictwa, absolwent Politechniki Krakowskiej (inż.), Szkoły Głównej Służby Pożarniczej (oficer pożarnictwa, od $1996 \mathrm{r}$. rzeczoznawca ds. zabezpieczeń przeciwpożarowych) oraz Akademii Górniczo-Hutniczej w Krakowie na kierunku: zarządzanie i marketing. W latach 2005-2007 był uczestnikiem comiesięcznych seminariów w zakresie Rozwoju Teorii i Praktyki Nauk o Zarządzaniu organizowanych przez Instytut Organizacji i Zarządzania w Przemyśle "Orgmasz" w Warszawie. Stopień doktora nauk technicznych uzyskał w roku 2000, na Wydziale Górniczym AGH, w dyscyplinie: górnictwo, specjalność: zarządzanie i marketing. Stopień doktora habilitowanego uzyskał w roku 2013, na Wydziale Bezpieczeństwa Narodowego AON, w dyscyplinie: nauki o bezpieczeństwie. Pełnił między innymi funkcje: zastępcy Komendanta Wojewódzkiego PSP w Katowicach, Dyrektora Wydziału Zarządzania Kryzysowego na UW w Katowicach, prorektora i zastępcy Komendanta SGSP w Warszawie.

KPT. MGR INŻ. ARTUR LUZAR - funkcjonariusz Państwowej Straży Pożarnej, inżynier bezpieczeństwa cywilnego. Pełni służbę na Wydziale Informatyki i Łączności Szkoły Aspirantów Państwowej Straży Pożarnej w Krakowie. Prowadzi zajęcia dydaktyczne w ramach przedmiotu: wsparcie komputerowe działań ratowniczych. Naukowo zajmuje się rolą mediów społecznościowych w kontekście szeroko pojętego bezpieczeństwa obywateli. 